\title{
Prevalence and Therapeutic Efficacy of Anthelmintic against Neoascaris vitulorum in Buffalo Populations from Sylhet District of Bangladesh
}

\author{
Shishir Kanu¹, Md. Shahidur Rahman Chowdhury ${ }^{1}$, Md. Abdus Sabur ${ }^{1}$, Md. Mahfujur \\ Rahman ${ }^{1}$, Kazi Mehetazul Islam², Md Bashir Uddn¹, Md. Rafqul Islam and Md. Mukter \\ Hossain $^{1, *}$
}

${ }^{1}$ Department of Medicine, Faculty of Veterinary, Animal and Biomedical Sciences, Sylhet Agricultural University, Sylhet-3100, Bangladesh

${ }^{2}$ Department of Parasitology, Faculty of Veterinary, Animal and Biomedical Sciences, Sylhet Agricultural University, Sylhet-3100, Bangladesh

\begin{abstract}
Background and Objectives: The epidemiological features of Neoascaris vitulorum infection in buffaloes are important to know their transmission and risk factors assessment as well treatment regimens. This study was conducted with the objectives of determining the prevalence of Neoascaris vitulorum infection in buffaloes in Sylhet district of Bangladesh and to evaluate the efficacy of anthelmintics against the parasite.

Materials and Method: A total of 211 fecal samples were collected from buffaloes and examined for the detection of parasitic eggs during the period from July 2017 to June 2018. For the determination of therapeutic efficacy, animals were randomly divided into 6 groups $\left(T_{0}, T_{i}, T_{1}, T_{2}, T_{3}, T_{4}\right)$ where each group consisting of 3 buffaloes. The group $T_{0}$ (negative control-non infected) and $T_{i}$ (positive control-infected) were treated only with phosphate buffer saline (PBS). The other four infected groups were treated as $T_{1}$ with albendazole, $T_{2}$ with piperazine citrate, $T_{3}$ with ivermectin and $T_{4}$ with combination of tetramisole $\mathrm{HCL}$ and oxyclosanide. Before trials day 0 and after treatment of 7th, 14th, 21st and 28th days fecal samples examined using McMaster technique.

Results: The overall prevalence was estimated $17.06 \%$ (36/211). The prevalence was higher among buffalo calves of below six months (39.28\%) followed by 6 months to 1 year, 1 to 2 years and above 2 years as $25 \%, 22.5 \%$ and $7.20 \%$ respectively. The infection rate was high in females $(20.0 \%)$ than males $(13.18 \%)$. The parasite was more prevalent in rainy $(21.42 \%)$ than summer $(16.67 \%)$ and winter $(14.29 \%)$ seasons. The EPG results revealed piperazine citrate was the most effective (100\%) against Neoascaris vitulorum. The percent efficacies of other anthelmintic used in this study were albendazole, ivermectin and combination of tetramisole $\mathrm{HCL}$ and oxyclozanide as $95.49 \%, 86.20 \%$ and $95.58 \%$ respectively.

Conclusion: The prevalence of Neoascaris vitulorum infection in buffalo at Sylhet district of Bangladesh was relatively high. The results revealed that piperazine citrate, tetramisole $\mathrm{HCL}$ and oxyclozanide combination are highly effective for the reduction of egg per gram (EPG) of Neoascaris vitulorum infection in buffalo. On the other hand ivermectin and albendazole were also around ninety percent effective respectively.
\end{abstract}

Keywords: Neoascaris vitulorum, prevalence, therapeutic efficacy, buffalo.

\section{INTRODUCTION}

Buffalo is one of the most important species of livestock as a source of dairy, meat, manure and drought in Bangladesh. Both swamp and river type buffaloes are found in Bangladesh [1]. The amount of meat, milk and income reduced because of factors such as death and sickness [2]. Neoascaris vitulorum, a nematode (round worm) of Bubalus and Boss species, founds mostly in tropical and subtropical climates throughout the world [3]. It is considered to be a major limiting factor in farms, due to high morbidity, mortality, loss of production and ineffective implementation of breeding programs [2]. It is among

${ }^{*}$ Address correspondence to this author at the Department of Medicine, Faculty of Veterinary, Animal and Biomedical Sciences, Sylhet Agricultural University, Sylhet-3100, Bangladesh; Tel: +88-01712054850;

E-mail: mukter.vetmed@sau.ac.bd the most destructive parasites of calves, the larvae of which undergo migration causing great damage to many organs, especially the liver and the intestine. It is responsible for up to fifty percent mortality in cattle and buffalo calves [4].This parasite is mainly transmitted through trans-placental and trans-mammary transmission, causing the disease characterized by severe diarrhea, weight loss and anorexia, particularly in buffalo calves between 1 and 3 months [5]. The disease in calves is the top most cause of morbidity and mortality [6]. Neoascariasis can be diagnosed on the basis of clinical signs, necropsy findings, fecal examination for eggs and serological tests. When the cow is pregnant the larvae migrate from the liver to the mammary gland and prior to parturition, to the milk through which the calf is infected [7]. An adult female parasite produces thousands of eggs daily. Egg fecundity ranges from 8000 to 100,000 eggs per gram 
(EPG) feces per day [8]. When a host ingests infective stage eggs, the larvae hatch out in the intestinal tract and migrate to the liver, lungs and other tissues [9]. A significant number of infections are fatal and ingestion of large number of eggs resulted in paralysis, conjunctivitis and opisthotonos. Higher prevalence of Neoascaris vitulorum was found up to 6 month of age [10]. Treatment of buffalo calves at different times after birth demonstrated that transmission from cow to the calf via milk occurs in all calves during the first 2 days after birth, decreases to $53 \%$ by 6 days, $10 \%$ by $8-9$ days and $2 \%$ from day 10 onwards [11]. Without treatment, the prevalence may reach $100 \%$ in calves, with mortality rates up to $80 \%$ as a result of weakening and dehydration [12]. Numerous broad spectrum anthelmintic are effective against adult worms and larvae in the gut (albendazole, febendazole, oxfendazole etc.). A few other narrow spectrum anthelmintic such as morantel, pyrantel and piperazine derivatives are effective against adult worms but may not control larvae and other roundworm species that often infect livestock simultaneously with Neoascaris vitulorum worms. In developed countries, the data on epidemiology of Neoascaris vitulorum are published in an efficient manner as an aid to combat infections more effectively. In contrast, in developing countries, little published information exists and data on the epidemiological aspect of Neoascaris vitulorum infections. Few researches related to gastrointestinal parasites in buffaloes have done in some regions of Bangladesh [13]. Very few numbers of epidemiological works on Neoascaris vitulorumin buffaloes has been done. This study was undertaken to determine the prevalence of Neoascaris vitulorum in buffaloes based on different age, sex, and seasons as well as to evaluate the therapeutic efficacy of different of anthelmintic against Neoascaris vitulorum infection.

\section{MATERIALS AND METHODS}

\section{Study Area and Period of Study}

The study was conducted in Sylhet district of Bangladesh. It was located in North-East part of

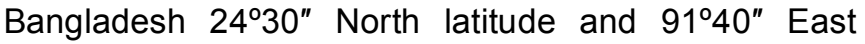
longitude. The average maximum and minimum temperatures were $34^{\circ} \mathrm{C}$ and $13^{\circ} \mathrm{C}$, respectively. The annual average rainfall was $3854.2 \mathrm{~mm}$ and humidity was $68.92 \%$. A lot of rivers are passing away through Sylhet district making natural pasture lands, which are suitable for buffalo rearing. The research work was conducted for a period of one year from July 2017 to June 2018.

\section{Collection of Fecal Samples}

During the study period, a total of 211 fecal samples from same number of household buffalo were collected from different places in the district. The fecal samples were collected directly from the rectum of buffaloes. Suitable containers like screw-capped wide mouthed glass bottles were used for sample collection and then transported to the laboratory for further examination. The sample collected from the remote areas was preserved in $4 \%$ formalin and then transport to the laboratory. Twenty (20) g of feces were collected from each buffalo and kept at $4^{\circ} \mathrm{C}$ beforeexamination. Identification was performed based on morphology of Neoascaris vitulorum eggs as described [14].

\section{Examination of Fecal Samples}

The color, consistency, presence of blood, mucus, dead worms and others was looked before microscopic examinationby naked eye. Microscopic examination of feces for detecting Neoascaris vitulorum eggs may vary from a simple direct smear to more complex methods involving centrifugation and McMaster techniques.

\section{Examination by Direct Smear Method}

This method was found useful only in the cases of heavy infections, small portion of fecal sample was directly placed on a grease free slide by a glass rod and 1-2 drop of saline was added to make a uniform suspension and then a cover slip was examined under low power microscope (10X).

\section{Examination by Indirect Method}

The purpose of methods is to detect light infections, to save time by concentrating the eggs in a small volume. In the Willis method about $1 \mathrm{ml}$ of mixed fecal specimen is diluted with $10-20 \mathrm{ml}$ of saturated common salt solution in a suitable narrow cylinder, which is filled the top with the saturated salt solution. A clean slide cover glass was slide ways over the top of the cylinder so that it is in contact with the saturated salt solution. After about 10-20 minutes the slide or cover glass was quickly removed and examine under a low power of microscope [16].

\section{Determination of the Efficacy of Different Anthel-} mintic against Neoascaris vitulorum Infection

\section{Selection of Experiment Site}

The highest number of buffalo population, high prevalence of neoascaris infection, good cooperation of 
the Veterinary were the criteria behind the selection. More than three quarter of the district consists of mostly high plain, water logged and low lying areas. In addition, the semi-scavenging systems rearing of buffalo were the most popular with the aim of having subsistent family income. The semi-scavenging buffaloes were feed on the grasses.

\section{Selection of the Experimental Buffaloes}

Household farms were selected randomly from different places. All buffaloes belonging to the 6 household farms were brought under parasitic screening. Up to $20 \mathrm{~g}$ of feces per buffalo was taken aseptically from the rectum. The direct smear methods as previously described [16] followed by the modified McMaster counting technique described earlier were used to screen Neoascaris vitulorum eggs in this study.

\section{Grouping of Experimental Buffaloes}

The buffaloes were randomly divided into 6 groups, each consisted of 3 buffaloes. Neoascaris infected specific treatment groups were selected by tagging a coin. The group was designated as $T_{0}, T_{i}$, and $T_{1}$ to $T_{4}$.

\section{Experimental Trials}

The group $T_{0}$ (negative control-non infected) and $T_{i}$ (positive control-infected) were treated only with PBS. $\mathrm{T}_{1}$ to $\mathrm{T}_{4}$ were treated with different anthelmintic. Schedules are presented in Table 1.

\section{Fecal Samples Collection and Egg Counting after Treatment}

Before trials (day 0) fecal samples were collected for parasitic egg count from the experimental buffaloes. After that weekly EPG count was done on day 7th, 14th, 21st and 28th post treatment. Fecal egg counts were done by McMaster technique. This method was based on the principle that the eggs floated up in a counting chamber. A special type of slide devised by McMaster is required in this technique.

\section{McMaster Egg Counting}

This was done by modified McMaster counting chamber as described [15]. This technique is useful in the determination of number of eggs per gram (EPG) of feces. Briefly $3 \mathrm{~g}$ of fecal samples were taken and $42 \mathrm{ml}$ of flotation solution was added to the sample and then thoroughly mixed so that it forms a homogenous mixture. The solution was then transferred through a sieve in order to remove the coarse particles and filled in test tubes and centrifuged at $2000 \mathrm{rpm}$ for 2 minutes. The supernatant was poured off and the sediment was agitated and again the tube was filled to the previous level with flotation solution. The upper fluid portion was poured in both chambers of McMaster slide with the help of pipette and no fluid was left in the pipette, as the eggs would rise quickly in the floatation fluid. Both chamber of fluid examined and number of eggs was multiplied by 100 to determine EPG.

\section{Statistical Analysis}

The analysis was performed by using statistical software SPSS (Version 17.0, SPSS Inc., Chicago, IL, USA) and Microsoft Excel 2007. Values of $P<0.001$ and $\mathrm{P}<0.05$ were considered as significant at $99.99 \%$ and $95 \%$ confidence, respectively.

\section{RESULTS}

A total of 211 fecal samples were collected from buffaloes and examined for detection of Neoascaris

Table 1: Infection Status and Treatment Schedule of Naturally Infected Experimental Buffaloes

\begin{tabular}{|c|c|c|c|c|c|c|}
\hline $\begin{array}{l}\text { Group of } \\
\text { buffaloes }\end{array}$ & $\begin{array}{l}\text { Status of } \\
\text { infection }\end{array}$ & $\begin{array}{l}\text { Treatment } \\
\text { regimens }\end{array}$ & $\begin{array}{l}\text { Trade name of } \\
\text { anthemintics }\end{array}$ & Manufacturer company & Doses & $\begin{array}{c}\text { Routes of } \\
\text { administration }\end{array}$ \\
\hline $\mathrm{T}_{0}$ & Non-infected & PBS & - & - & - & Orally \\
\hline $\mathrm{T}_{\mathrm{i}}$ & Infected & PBS & - & - & - & Orally \\
\hline $\mathrm{T}_{1}$ & Infected & Albendazole & $\begin{array}{l}\text { Alben®-vet } \\
\text { (bolus) }\end{array}$ & $\begin{array}{l}\text { Eskayef Pharmaceuticals } \\
\text { Ltd., Bangladesh }\end{array}$ & $\underset{\mathrm{bwt}^{\mathrm{a}}}{7.5 \mathrm{mg} / \mathrm{kg}}$ & Orally \\
\hline $\mathrm{T}_{3}$ & Infected & Ivermectin & $\begin{array}{c}\text { I-ver® } \\
\text { (injection) }\end{array}$ & $\begin{array}{c}\text { The Globe } \\
\text { Pharmaceuticals Ltd., } \\
\text { Bangladesh }\end{array}$ & $\begin{array}{c}0.5 \mathrm{ml} / 25 \\
\mathrm{~kg} \mathrm{bwt}^{\mathrm{a}}\end{array}$ & ${ }^{\mathrm{b}} \mathrm{S} / \mathrm{C}$ injection \\
\hline $\mathrm{T}_{4}$ & Infected & $\begin{array}{l}\text { Tetramisole and } \\
\text { Oxyclosanide }\end{array}$ & $\begin{array}{l}\text { Levanid }{ }^{\circ} \\
\text { (bolus) }\end{array}$ & $\begin{array}{c}\text { The ACME Laboratories } \\
\text { Ltd., Bangladesh }\end{array}$ & $\underset{\mathrm{bwt}^{\mathrm{a}}}{7.5 \mathrm{mg} / \mathrm{kg}}$ & Orally \\
\hline
\end{tabular}

${ }^{\mathrm{a}}$ bwt = body weight; ${ }^{\mathrm{b}} \mathrm{S} / \mathrm{C}=$ subcutaneous. 
Table 2: Prevalence of Neoascaris vitulorum Infection in Buffaloes

\begin{tabular}{|c|c|c|c|}
\hline Variables & No. of animal examined & No. of positive animal & Prevalence \\
\hline \multicolumn{4}{|l|}{ Age } \\
\hline Up to 6 months & 28 & 11 & $39.28 \%$ \\
\hline 6 moths- 1 year & 40 & 10 & $25.0 \%$ \\
\hline $1-2$ years & 31 & 7 & $22.5 \%$ \\
\hline Above 2 years & 111 & 8 & $7.20 \%$ \\
\hline Total & 211 & 36 & $17.06 \%$ \\
\hline \multicolumn{4}{|l|}{ Sex } \\
\hline Female & 120 & 24 & $20.0 \%$ \\
\hline Male & 91 & 12 & $13.18 \%$ \\
\hline Total & 211 & 36 & $17.06 \%$ \\
\hline
\end{tabular}

Table 3: Seasonal Prevalence of Neoascaris vitulorum Infection in Buffaloes

\begin{tabular}{|c|c|c|c|}
\hline Name of seasons & Total no. of animals examined & No. of affected animals & Prevalence \\
\hline \hline Summer & 78 & 13 & $16.67 \%$ \\
\hline Rainy & 56 & 12 & $21.42 \%$ \\
\hline Winter & 77 & 11 & $14.29 \%$ \\
\hline Overall & 211 & 36 & $17.06 \%$ \\
\hline
\end{tabular}

Table 4: Egg Per Gram of Feces in Experimental and Control Group of Buffaloes after Treatment

\begin{tabular}{|c|c|c|c|c|c|}
\hline Experimental group & Day 0 & Day 7 & Day 14 & Day 21 & Day 28 \\
\hline \hline$T_{0}$ & 0 & 0 & 0 & $812 \pm 18.28^{*}$ & $826 \pm 18.6^{*}$ \\
\hline$T_{i}$ & $746 \pm 20.39$ & $772 \pm 20.83^{*}$ & $800 \pm 18.17^{*}$ & $200 \pm 57.73^{*}$ & $33 \pm 37.12^{*}$ \\
\hline$T_{1}$ & $733 \pm 88.22$ & $533 \pm 57.33^{*}$ & $366 \pm 66.66^{*}$ & $66 \pm 33.33^{*}$ & $0^{*}$ \\
\hline$T_{2}$ & $966 \pm 88.18$ & $533 \pm 66.67^{*}$ & $233 \pm 33.33^{*}$ & $121 \pm 18.45^{*}$ & $64 \pm 9.22^{*}$ \\
\hline$T_{3}$ & $464 \pm 23.69$ & $178 \pm 18.4^{*}$ & $135 \pm 14.28^{*}$ & $121 \pm 6.78^{*}$ & $34 \pm 2.21^{*}$ \\
\hline$T_{4}$ & $770 \pm 51.47$ & $367 \pm 23.85^{*}$ & $185 \pm 6.52^{*}$ & $3^{*}$ & \\
\hline
\end{tabular}

*Significant at $1 \%$ level $(\mathrm{P}<0.01)$.

vitulorum eggs. The overall prevalence of the infection was estimated $17.06 \%$ (36/211). The prevalence was higher among buffalo calves of below six months (39.28\%) followed by 6 months to 1 year, 1 to 2 years and above 2 years as 25\%, 22.5\% and $7.20 \%$ respectively. The infection rate was high in females $(20.0 \%)$ than males $(13.18 \%)$. The parasite was more prevalent in rainy $(21.42 \%)$ than summer $(16.67 \%)$ and winter $(14.29 \%)$ seasons. Before trials day 0 and after treatmentof 7th, 14th, 21st and 28th days fecal samples examined using McMaster technique. The EPG results revealed piperazine citrate was the most effective (100\%) anthelmintic against Neoascaris vitulorum. The percent efficacies of other anthelmintic used in this study were albendazole, ivermectin and combination of tetramisole $\mathrm{HCL}$ and oxyclozanide as $95.49 \%, 86.20 \%$ and $95.58 \%$ respectively.

The efficacies of the products were evaluated on the percentage of reduction in mean egg count after treatment compared to the mean EPG before treatment. A significant $(P<0.01)$ reduction of EPG count was found on 7 th, 14 th, 21st, 28th day of treated buffaloes of group $T_{1}$ to $T_{4}$ respectively. 
Table 5: Determination of Therapeutic Efficacy of Different Anthelmintic against Neoascaris vitulorum in Buffaloes

\begin{tabular}{|c|c|c|c|c|}
\hline \multirow{2}{*}{ Treatment group } & \multicolumn{4}{|c|}{ Percentage of EPG reduction } \\
\cline { 2 - 5 } & Day 7 & Day 14 & $72.71 \%$ & Day 21 28 \\
\hline \hline $\begin{array}{c}\mathrm{T}_{1} \\
\text { (Albendazole) }\end{array}$ & $27.28 \%$ & $50.06 \%$ & $93.49 \%$ \\
\hline $\begin{array}{c}\mathrm{T}_{2} \\
\text { (Piperazinecitrate) }\end{array}$ & $44.82 \%$ & $75.87 \%$ & $700 \%$ \\
\hline $\begin{array}{c}\mathrm{T}_{3} \\
\text { (Ivermectin) }\end{array}$ & $61.63 \%$ & $70.70 \%$ & $73.92 \%$ & $86.20 \%$ \\
\hline $\begin{array}{c}\mathrm{T}_{4} \\
\text { (Tetramisole and Oxyclosanide) }\end{array}$ & $52.34 \%$ & $75.97 \%$ & $84.29 \%$ & $95.58 \%$ \\
\hline
\end{tabular}

\section{DISCUSSION}

A total of 211 numbers of fecal samples were examined for the presence of Neoascaris vitulorum infection. 36 samples were found positive for Neoascaris vitulorum infection, giving an overall prevalence of $17.06 \%$. Higher incidence of Neoascaris vitulorum infection in buffalo calves have also been reported from different parts of India and abroad [1621]. The variation in the prevalence rate of the Neoascaris vitulorum infection may be associated with different factors like different geo-climatic conditions, poor hygienic condition of the shed, health care management and sample variation.

Among age of animals, highest incidence was recorded in the age group of $<0.5$ year followed by 6 months to 1 year, 1 to 2 and above 2 years. Similar findings were reported by others [22-23]. The cause for higher incidence of Neoascaris vitulorum infection in the younger age in the present study may be due to pre-natal infection i.e. trans-placental infection at the later stage of pregnancy and transfer of 3rd stage larvae in colostrum and milk or post-natal infection due to poor managemental condition. The lower rate of incidence in older calves may be due to elimination of worm burden or to immunity gained by the animals from repeated infection with the infective larvae through colostrum or milk [14].

Among samples, 120 were from female and 91 were from male buffaloes. Higher prevalence of Neoascaris vitulorum infection was recorded in female calves than male calves. Similarly higher prevalence in female calves than male buffalo were reported [17, 21]. The sex of the buffalo calves had no significant influence on the incidence rate [23] while others reported higher incidence in males than females [21, 24]. Though absolute reason for higher infection in females has not been well explained by previous workers, it is commonly believed that, since female calves are allowed to suckle frequently and more milk than that of male calves, they are more exposed to higher risk of infection through trans-mammary route. The reason for slightly prevalence in females than males the present study may also be attributed to the above fact and variation in the number of fecal samples examined.

Prevalence of Neoascaris vitulorum infection was recorded be highest during rainy season followed by summer and winter. Similar findings were also recorded [16, 18, 25-28] in buffalo calves. Higher incidence in rainy season may be due to higher rainfall and relative humidity that favors the maximum embryonation, development and dissemination of the exogenous stage of the parasite. High rainfall provides suitable molarities of salt present in the soil, which is an important factor for ecdysis [14].

The group $T_{0}$ (negative control-non infected) and $T_{i}$ (positive control-infected) were treated only with PBS. Other four groups $\left(T_{1}, T_{2}, T_{3}, T_{4}\right)$ were treated with different types of anthelmintics. This study showed the therapeutic efficacy of different types of anthelmintics. The number of eggs gradually decreased $T_{0}$ (negative control-non infected) and $\mathrm{Ti}$ (positive control- infected) EPG values were increased. The result of the comparative efficacies of different anthelmentics showed that piperazine citrate, tetramisole HCL and oxyclozanide combination against Neoascaris vitulorum in naturally infected buffaloes were highly effective. These results are similar to [29] report $99.9 \%$ efficacy of piperazine against neoascariasis infection in buffalo calves. piperazine citrate was $100 \%$ effective against ascarid worms in buffalo [30]. A single administration of Levamisole at the age of ten days killed the adult and immature intestinal worms and prevented 
recontamination of the environment and the efficacy of pyrantel and febendazole was $100 \%$ and piperazine $57 \%$ against Neoascaris vitulorum infection in buffalo [11]. Another study of the therapeutic efficacy of ivermectin, and albendazole against Neoascaris vitulorum infection in buffalo was recorded to be 93.33 $\%$ and $84.61 \%$ respectively [25] which is similar in case of albendazole but in case of Ivermectin the efficacy was slightly lower. The findings of the present study reveal that piperazine citrate, tetramisole $\mathrm{HCL}$ and oxyclozanide combination are highly effective for the reduction of EPG of Neoascaris vitulorum infection in buffalo. On the other hand ivermectin and albendazole are also effective against Neoascaris vitulorum infection.

\section{CONCLUSION}

This study concluded that the overall prevalence of Neoascaris vitulorum infection in buffalo at Sylhet district of Bangladesh was relatively high. The findings of this study revealed that piperazine citrate, tetramisole $\mathrm{HCL}$ and oxyclozanide combination are highly effective for the reduction of EPG of Neoascaris vitulorum infection in buffalo. On the other hand ivermectin and albendazole was also around ninety percent effective. The findings of the present study may help the future researchers to explore the details and wide therapeutic uses in Bangladesh for the treatment and control of Neoascaris infestation in buffaloes. Further studies on the prevalence of Neoascaris vitulorum infection would clarify the efficacy of the anthelmintics widely used in different animal species and livestock management system in Bangladesh.

\section{ACKNOWLEDGEMENT}

The authors gratefully express their gratitude to Sylhet Agricultural University Research System (SAURES) for financial support to complete this research successfully.

\section{CONFLICT OF INTEREST}

The authors declare that there is no conflicting interest with regards to the publication of this manuscript.

\section{REFERENCES}

[1] Latif MA. Buffalo Production in Bangladesh: problems and prospects. Proceeding of the 1st Asian Buffalo Association Congress, Khon Kaen, Thailand January 17-21, 1994.

[2] Chowdhury N, Tada I. Helminths of domesticated animals in Indian subcontinent, In: Helminthology. Springer-Verlag, Narosa Publishing House, 1994; pp. 73-120. https://doi.org/10.1007/978-3-642-78838-3 3
Starke-Buzetti W. Neoascaris vitulorumin livestock. In: Holland C. and Smith H. (Editors). Neoascaris: the Enigmatic Parasite. CABI Publishing, Wallingford, 2006; pp. 260-278. https://doi.org/10.1079/9781845930264.0260

[4] Srivastava AK, Sharma DN. Studies on the occurrence, clinical features, and pathomorphological aspects of ascariasis in buffalo calves. Vet Res J 1981; 4: 160-162.

[5] Wickramasinghe S, Yatawara L, Rajapakse RPVJ, Agatsuma T. Toxocaravitulorum (Ascaridida: Nematoda): mitochondrial gene content, arrangement, and composition compared with other Toxocara spp. Mol Biochem Parasit 2009; 166: 89-92. https://doi.org/10.1016/j.molbiopara.2009.02.012

[6] Dorchies P. Neoascaris vitulorum and Strongyloides papillosus: the enemies of very young calves. Bulletin GTV 2010; 52: 55-62.

[7] Dorny P, Devleesschawer B, Stoliaroff V, Sothy M, Chea R, Chea B, Sourloing H, Samuth S, Kong S, Nguong K, Sorn S, Holl D. Prevalence and associated risk factors of Neoascaris Vitulirum infections in buffalo and cattle calves in three provinces of central Cambodia. Korean J Parasitol 2015; 53: 197-200.

https://doi.org/10.3347/kjp.2015.53.2.197

[8] Li K, Li JK, Nabi F, Gao JF, Han JM. Seroprevalence of bluetongue virus in domestic yaks in Tibetan regions of china based on circulating antibodies. Trop Anim Health Prod 2015; 47: 1221-1223.

https://doi.org/10.1007/s11250-015-0853-0

[9] Nagataki M, Tantrawatpan C, Agastsuma T, Sugiura T. Mitochondrial DNA sequences of 37 collarspinedechinostomes in Thailand and Lao PDR reveals presence of two species. Infect Genet Evol 2015; 35: 56-62. https://doi.org/10.1016/j.meegid.2015.07.022

[10] Zimmerman J, Karriker L, Ramirez A, Schwartz K, Stevenson G. Diseases of Swine. $10^{\text {th }}$ edition. Wiley-Blackwell, Oxford, 2012; pp. 213-219.

[11] Roberts J. The extra parasitic life cycle of Neoascaris vitulorumin the village environment of Sri Lanka. Vet Res Commun 1989; 13: 377-388.

https://doi.org/10.1007/BF00346070

[12] Roberts J. Toxocara vitulorum in Ruminants. Helminthological Abstracts 1993; 62: 151-174.

[13] Pradhan KB, Thakur DK, Sudhan NA. Incidence of gastrointestinal parasites in suckling calves in Ranchi. J Res Birsa Agric Univ 1991; 3: 123-123.

[14] Soulsby EJL. Helminths, Arthropod and Protozoa of Domesticated Animals, 7th ed. 1982; pp. 35-740.

[15] Urquhart GM, Aremour J, Dunchan JL, Dunn AM and Jeninis FW. Veterinary parasitology $2^{\text {nd }}$ edition. The University of Glasgow, Blackwell sciences, Scotland 1996; pp. 3-137.

[16] Devi HU, Ansari MZ, Singh SK, Devi KHB. Prevalence and epidemiology of Neoascarisvitulorumin cow and buffalo calves in and around Ranchi, Bihar. Indian J Anim Sci 2000; 70: 817-819.

[17] Agnihotri RK, Katoch R. Prevalence of intestinal helminthic and coccidial infections in cow calves in Kangra valley of Himachal Pradesh. Vet Pract 2003; 4: 13-15.

[18] Kumari P, Sinha SRP, Sinha S, Kumar R, Verma SB, Mandal KG. Prevalence and control of Neoascaris vitulorumin bovine calves. Vet Parasitol 2004; 18: 47-49.

[19] Kumar A, Verma SP. Prevalence of gastrointestinal helminth infection in calves. Indian J Vet Med 2006; 26: 43-44.

[20] Raza MA, Murtaza S, Bachaya HA, Qayyum A, Zaman MA. Point prevalence of Neoascaris vitulorumin large ruminants slaughtered at Multan abattoir. Pak Vet J 2010; 30: 242-244.

[21] Islam KBMS, Shil NK, Islam MT, Das SK. Incidence of ascariasis in calves reared under rural conditions. Bangladesh J Vet Med 2005; 3: 21-23.

https://doi.org/10.3329/bjvm.v3i1.11336 
[22] Srinivasa RR, Uday KM, Ram R. Incidence of Neoascaris vitulorum in buffalo calves around Hyderabad, India. Vet Parasitol 2000; 14: 79-80.

[23] Das G, Kalita DN, Phukan A, Dutta TC, Mahato G and Phukan SC. Therapeutic efficacy of anthelmintics in management of Toxocara vitulorum infection in calves. Int $\mathrm{J}$ Chem Stud 2018; 6: 2799-2802.

[24] Nasreen A, Mohammad IR, Mirbahar KB, Memon MI. Helminthiasis in buffaloes as influenced by age and sex. Pak Vet J 2000; 20: 154-156.

[25] Hafiz A, Rehman A, Hazarika RA, Islam S, Bhattacharyya DK. Prevalence of gastrointestinal nematodiasis in swamp buffalo calves in an organized farm of Assam. Indian $\mathrm{J}$ Vet Med 2009; 29: 119-120.

[26] Rajkhowa S, Hazarika GC. Prevalence of intestinal nematodes in female calves of greater Guwahati of Assam. Indian Vet J 2001; 78: 449-451.
[27]

Sahoo N, Mohanty TN, Ray TK. Seasonal incidence of gastrointestinal helminthic infection in cattle of Phulbari district, Orissa. Indian Vet J 2003; 80: 622-624.

[28] Bhattacharyya DK and Ahmed K. Prevalence of helminth infection in cattle and buffaloes. Indian Vet J 2005; 82: 900901.

[29] Sinha HK, Singh SP, Singh VK, Singh SRP. Efficacy of various anthelmintics on the mortality of the infective larvae of NeoascarisVitulorum and treatment of calf ascariasis. Indian J Anim Sci 1987; 57: 185-188.

[30] Danek J, Strosova Z, Kinkorova J. Anthelmintic efficacy of piperazine adipate and citrate in granular form. Biologizace Achemizace Zivocisne Vyroby-Veterinarian 1983; 19: 71-81.

\section{https://doi.org/10.6000/1927-520X.2021.10.03}

() 2021 Kanu et al.; Licensee Lifescience Global.

This is an open access article licensed under the terms of the Creative Commons Attribution Non-Commercial License (http://creativecommons.org/licenses/by-nc/3.0/) which permits unrestricted, non-commercial use, distribution and reproduction in any medium, provided the work is properly cited. 